Syntax Literate : Jurnal Ilmiah Indonesia p-ISSN: 2541-0849

e-ISSN : 2548-1398

Vol. 5, No. 2 Februari 2020

\title{
SI KEREN (SISTEM INFORMASI KETERANGAN RENCANA KABUPATEN) KABUPATEN DEMAK
}

\section{Arief Susanto, Evanita dan Muhamad Bakhar}

Teknik Informatika, Universitas Muria Kudus dan Teknik Komputer, Politeknik Harapan Bersama

Email: arief.susanto@umk.ac.id, evanita@umk.ac.id dan

muhammadbakhar@gmail.com

\begin{abstract}
Demak Regency has an area of 89,743 Ha, and most of the area is paddy land with an area of 51,558 $\mathrm{Ha}(57.47 \%)$ and the rest is gardens, buildings and ponds 38,185 $\mathrm{Ha}$ (42.53\%). Existing paddy consists of technical watered paddy $37.25 \%$ and rainfed paddy $19.33 \%$. As for the dry land $14.93 \%$ is used for tegal / garden; $17.12 \%$ is used for buildings and yards; and $10.63 \%$ used for ponds. Administratively it is divided into 14 districts. As the entrance of the provincial city from the east, based on the Demak Regent Regulation Number: 51 of 2016 concerning Position, Organizational Structure, Duties and Functions and Work Procedures of the Public Works and Spatial Planning Office of Demak Regency, it is stated that the Public Works and Spatial Planning Office has the task of carrying out some of the duties of the Bupati in the field of Public Works. In helping the Demak District Public Works and Spatial Planning Office carry out its tasks an electronic information system has been made, which is able to overlay the planning, monitoring and control of the spatial plans. This system will gradually facilitate regional mapping, simplify the naming pattern of the spatial plans area, and give control to the licensing process that is not suitable for designation.
\end{abstract}

Keywords: Si Keren, Spatial Plans, Demak

\section{Abstrak}

Kabupaten Demak memliliki luas wilayah sebesar $89.743 \mathrm{Ha}$, dan sebagian besar wilayah merupakan lahan sawah yaitu seluas $51.558 \mathrm{Ha}(57,47 \%)$ dan selebihnya adalah kebun, bangunan dan tambak $38.185 \mathrm{Ha}(42,53 \%)$. Sawah yang ada terdiri dari sawah berpengairan teknis 37,25\% dan sawah tadah hujan 19,33\%. Sedangkan untuk lahan kering 14,93\% digunakan untuk tegal/kebun; 17,12\% digunakan untuk bangunan dan halaman; serta 10,63\% digunakan untuk tambak. Secara administratif terbagi menjadi 14 kecamatan. Sebagai pintu masuk kota provinsi dari arah timur, atas dasar Peraturan Bupati Demak Nomor : 51 Tahun 2016 tentang Kedudukan, Susunan Organisasi, Tugas dan Fungsi Serta Tata Kerja Dinas Pekerjaan Umum dan Penataan Ruang Kabupaten Demak disebutkan bahwa Dinas Pekerjaan Umum dan Penataan Ruang mempunyai tugas melaksanakan sebagian tugas Bupati di bidang Pekerjaan Umum. Dalam membantu Dinas Pekerjaan Umum dan Penataan Ruang Kabupaten Demak melaksanakan tugasnya dibuatlah sistem informasi secara elektronik, yang mampu melakukan overlay terhadap perencanaan, monitoring dan 
pengendalian RTRW. Sistem ini akan secara bertahap memudahkan pemetaan wilayah, menyederhanakan pola penamaan kawasan RTRW, serta memberikan kendali pada proses perijinan yang tidak sesuai peruntukan.

Kata kunci: Si Keren; RTRW; Demak

\section{Pendahuluan}

Pelaksaan otonomi daerah selain berdasarkan pada acuan hukum, juga sebagai tuntutan dunia global, dimana pemberdayaan dan pembukaan daerah otonomi menjadi lebih luas, lebih nyata dan bertangung jawab, khususnya mengenai pengaturan dan pengelolaan sumber potensi yang dimiliki oleh masing-masing daerah (Harmono, 2018). Salah satunya adalah daerah perkotaan.

Kemajuan industri, teknologi dan transportasi di perkotaan ditandai dengan terus bertumbuhnya pembangunan secara akselerasi. Selain sering mengubah konfigurasi alami lahan, pembangunan tersebut juga sering menyita lahan-lahan perkotaan dan berbagai bentuk lahan terbuka lainnya. Akibatnya RTH (Ruang Terbuka Hijau) yang ada sering dianggap sebagai lahan yang tidak ekonomis dan hanya sebagai cadangan. Di lain pihak kemajuan pembangunan dan transportasi tersebut menjadi tolak ukur kesejahteraan masyarakat kota, tidak hanya itu pencemaran lingkungan dan ketidak nyamanan sebagai dampak negatif dari adanya pembangunan tersebut. Untuk mengatasi kondisi lingkungan kota seperti ini sangat diperlukan RTH sebagai solusi yang relatif lebih murah, aman, dan sehat (Nugroho, 2015).

Menimbang masalah di atas, maka perlu adanya penataan ruangan kota sebagai wujud usaha efisiensi dan efektifiktas sumberdaya kota tersebut. Baik sumberdaya alam maupun sumberdaya lainnya. Ruang-ruang kota yang ditata terkait dan saling berkesinambungan ini mempunyai berbagai pendekatan dalam perencanaan dan pembangunannya. Tata guna lahan, sistem transportasi, dan sistem jaringan utilitas merupakan tiga faktor utama dalam menata ruang kota (Dewiyanti, 2011). Dalam perkembangan selanjutnya, konsep ruang kota selain dikaitkan dengan permasalahan utama perkotaan yang akan dicari solusinya juga dikaitkan dengan pencapaian tujuan akhir dari suatu penataan ruang yaitu untuk kesejahteraan, kenyamanan, serta kesehatan warga dan kotanya (Krisnawati, 2017).

Syarat berbagai kepentingan dari kota yang semakin sesak dengan jumlah penduduk dan makin bertambah kompleks aspek permasalahan kota menyebabkan keberadaan Ruang Terbuka Hijau sebagai paru-paru kota tinggal menunggu nasib dan waktu untuk Ruang Terbuka Hijau masih bisa tetap. Pemangkasan demi pemangkasan luasan RTH dan beralihnya lahan-lahan RTH menjadi fungsi peruntukan yang lain seperti pom bensin, pos polisi, tempat penampungan sampah sementara dan sebagian area bahkan telah menjadi gedung-gedung.

Beberapa persoalan terkait tata ruang yang menjadi konsen adalah permasalahan koversi penggunaan lahan, menurunnya kualitas ruang karena eksklusifitas permukiman, kemudian kesenjangan pembangunan kawasan antar wilayah. Sedangkan solusi untuk mengatasi isu permasalahan tersebut, yaitu dengan mengacu pada UU No. 
26/2007 mengenai Penataan Ruang. Pertama, rencana detail tata ruang sebagai konsep pembangunan berbasis rencana, dimana hal itu sebagai cara untuk memeriksa pelanggaran pemanfaatan tata ruang serta sebagai dasar penegakan sanksi dan hukum. Sebagai contoh hak penarikan kepemilikan tanah, penghancuran gedung, dan lainnya. Selain itu juga dengan pemberian sangsi merupakan solusi untuk menangani para pelanggar tata ruang. Dengan Undang-undang Nomor 26 tahun 2007 tentang Penataan Ruang akan ada sanksi bagi siapapun (termasuk pemerintah) yang melanggar penggunaan lahan dan bangunan yang sudah ditetapkan di RTRW (Rencana Tata Ruang Wilayah) Kota (Paramesti, 2016). Ada 3 bentuk sangsi yaitu sangsi adiministrasi (termuat di Pasal 62 sampai 64), sangsi perdata (Pasal 66, 67, dan 75) dan sangsi pidana (Pasal 69 sampai 74).

Untuk menghindari terjadinya masalah-masalah perkotaan yang semakin rumit pada masa yang akan datang dan menghindari terulangnya masalah-masalah perkotaan yang telah terjadi dimasa lampau, perlu dilakukan perencanaan kedepan sesuai dengan arah pembangunan dengan dibuat pedoman pengaturan dan program-program pembangunan kota jangka panjang yang berupa RTRW. Sebagai pintu masuk kota propinsi dari arah timur, atas dasar Peraturan Bupati Demak Nomor : 51 Tahun 2016 Tentang Kedudukan, Susunan Organisasi, Tugas dan Fungsi Serta Tata Kerja Dinas Pekerjaan Umum dan Penataan Ruang Kabupaten Demak disebutkan bahwa Dinas Pekerjaan Umum dan Penataan Ruang mempunyai tugas melaksanakan sebagian tugas Bupati di bidang Pekerjaan Umum. Dalam membantu Dinas Pekerjaan Umum dan Penataan Ruang Kabupaten Demak melaksanakan tugasnya dirasa perlu adanya sistem informasi secara elektronik, yang mampu melakukan overlay terhadap perencanaan, monitoring dan pengendalian RTRW.

\section{Metode Penelitian}

Penelitian yang dilaksanakan ini termasuk pada penelitian deskriptif kualitatif dan penelitian tindakan dengan melakukan observasi, wawancara mendalam, dan pengumpulan dokumen yang berhubungan dengan RTRW Kabupaten Demak. Data primer dari wawancara dengan Dinas Pekerjaan Umum dan Penataan Ruang Kabupaten Demak berupa catatancatatan khusus tentang seluruh kebutuhan yang diperlukan untuk membangun Si Keren. Sedangkan data sekunder merupakan kumpulan peta-peta kawasan wilayah dan dokumen persyaratan perijinan pemanfaatan ruang

\section{Hasil dan Pembahasan}

\section{Perancangan Si Keren}

Penggambaran hubungan yang saling terikat antara sistem dengan pengguna dalam hal ini adalah staf yang bersangkutan dan Kabid (Kepala bidang). DFD atau Data Flow Diagram digunakan untuk menggambarkan hubungan tersebut. Pengguna menjalankan aplikasi sistem dengan cara memberikan perintah dan masukan data sesuai dengan keinginan pengguna, sementara sistem memberikan keluaran berupa tampilan yang dibutuhkan pengguna dan keluaran tersebut 
ditampilkan dilayar monitor serta dapat dicetak, mulai dari Context Diagram dan DFD Level. Desain DFD adalah sebagai berikut:

a. Context Diagram

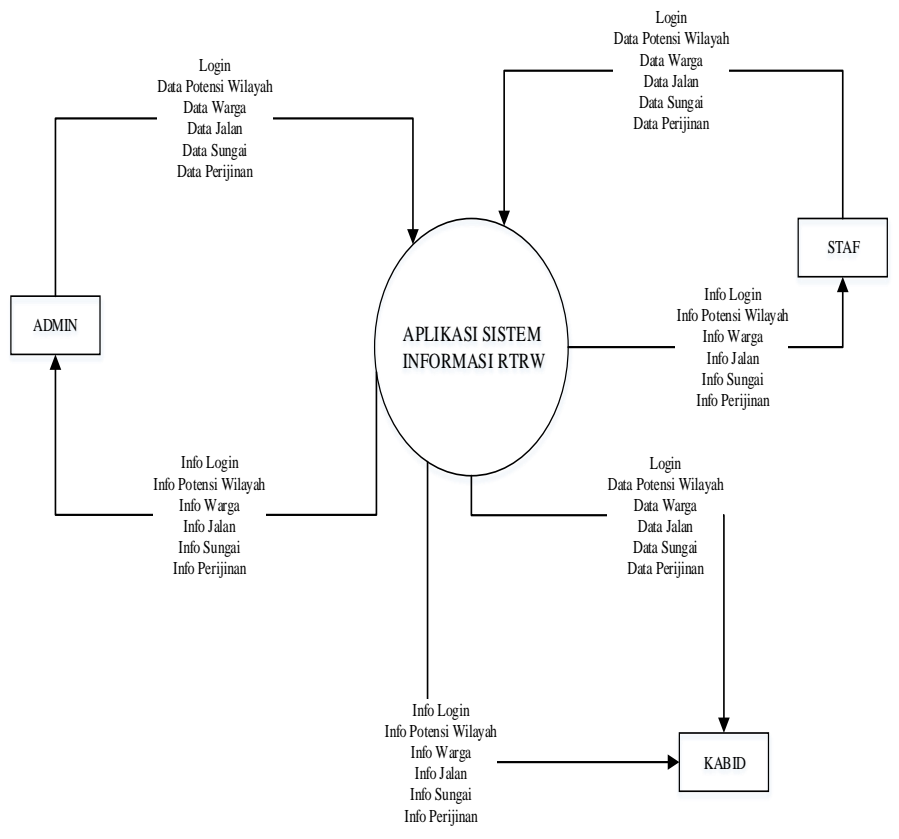

Gambar 1 Context Diagram

Terpusat pada Aplikasi Sisitem Informasi RTRW yang dapat mengolah data dan memberikan info pada pengguna setelah admin dan pengguna menginputkan data dimana pengguna harus login terlebih dahulu untuk dapat masuk ke sistem. Berbagai data sesuai rancangan sistem berupa data potensi wilayah, data warga, data sungai, data jalan dan data perijinan akan menjadi menu-menu utama dalam sistem yang didalamnya terdapat beberapa sub menu untuk mempermudah proses pengolahan data.

b. DFD Level 1 


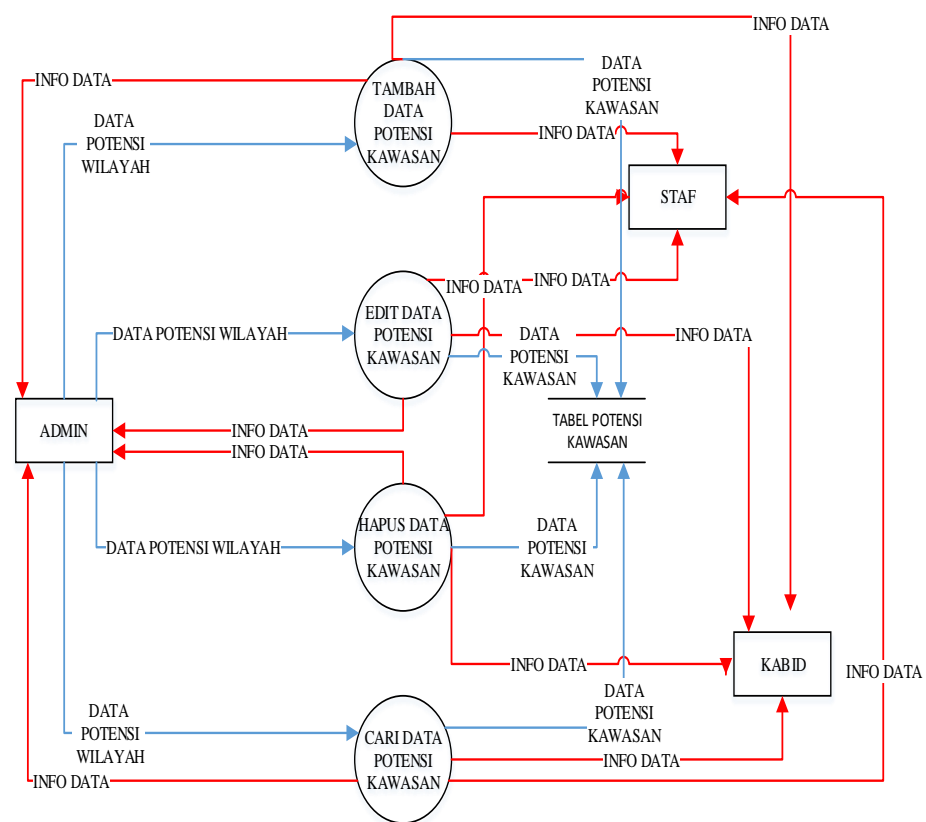

Gambar 2 DFD Level 1

DFD Level 1 menggambarkan alur menu Data Potensi Wilayah yang didalamnya terdapat proses tambah, edit, hapus dan cari data tersebut. Ke empat proses tersebut akan mempengaruhi isi tabel potensi kawasan,misalkan jika ada proses tambah, data pada tabel akan bertambah. Sama halnya dengan proses edit, hapus. Proses cari digunakan jika pengguna ingin mengetahui isi data dengan ketentuan tertentu, misalkan berdasarkan kawasan budidaya, kawasan lindung atau kawasan rawan bencana alam. Sama halnya dengan DFD Level 2 hingga Level 5 mewakili alur menu per data yang ada pada context diagram.

c. DFD Level 2 Data Warga

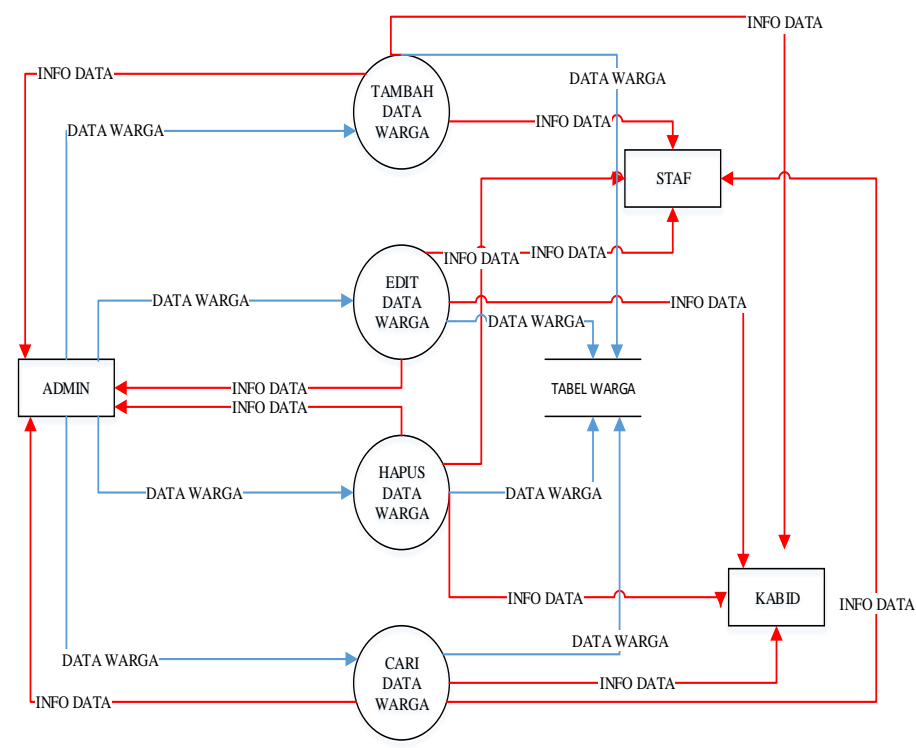

Gambar 3 DFD Level 2 
d. DFD Level 3 Data Jalan

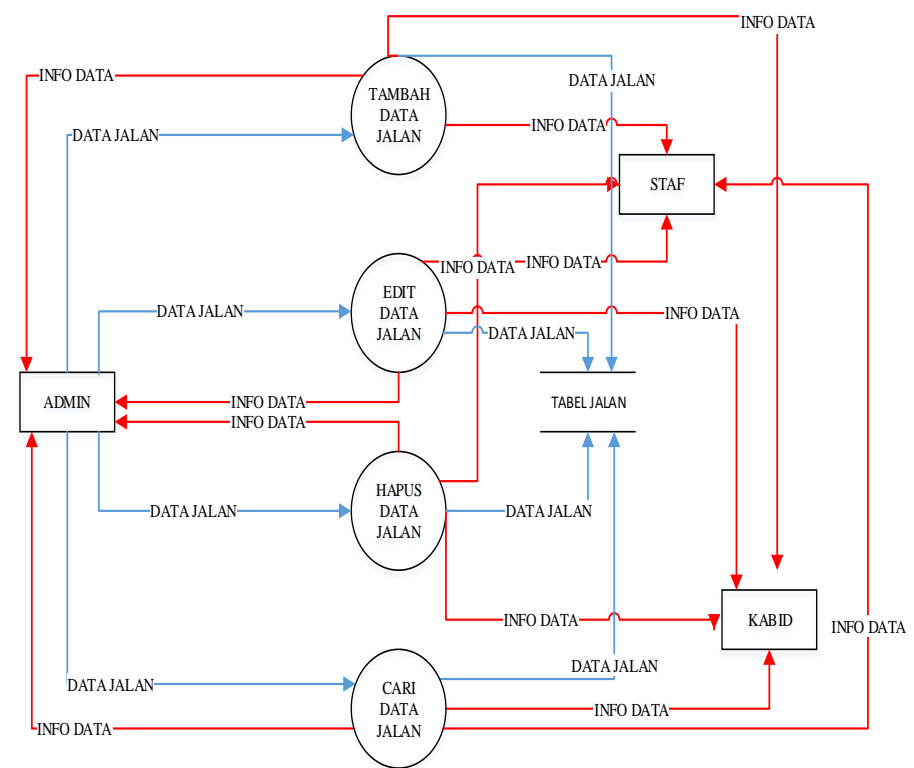

Gambar 4 DFD Level 3

e. DFD Level 4 Data Sungai

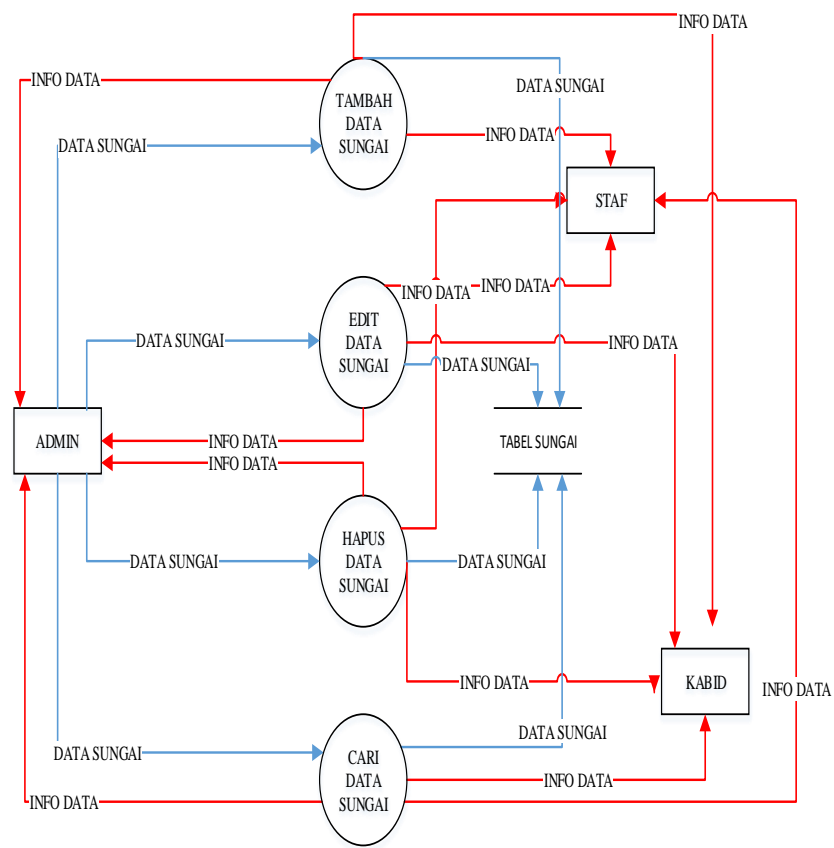

Gambar 5 DFD Level 4 


\section{f. DFD Level 5 Data Perijinan}

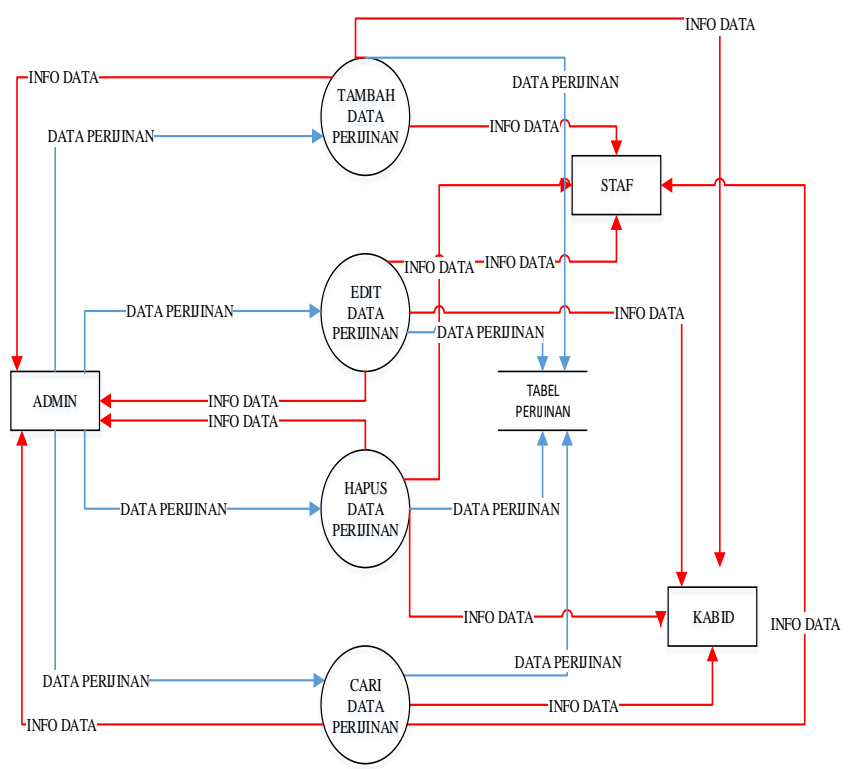

\section{Gambar 6 DFD Level 5}

\section{Implementasi Si Keren}

Implementasi Si Keren dapat di akses melalui 2 cara yaitu melalui website dan juga aplikasi Android. Keduanya tetap mempunyai fungsi dan cara kerja yang sama, hanya saja tampilannya yang sedikit berbeda.

a. Halaman Utama Sikeren

Halaman Utama yaitu halaman yang dapat diakses semua orang, dihalaman ini terdapat menu untuk pengajuan permohonan dengan yaitu Form Permohonan. Dan juga ada data pemohon untuk melihat permohonan sudah tersimpan di sistem.

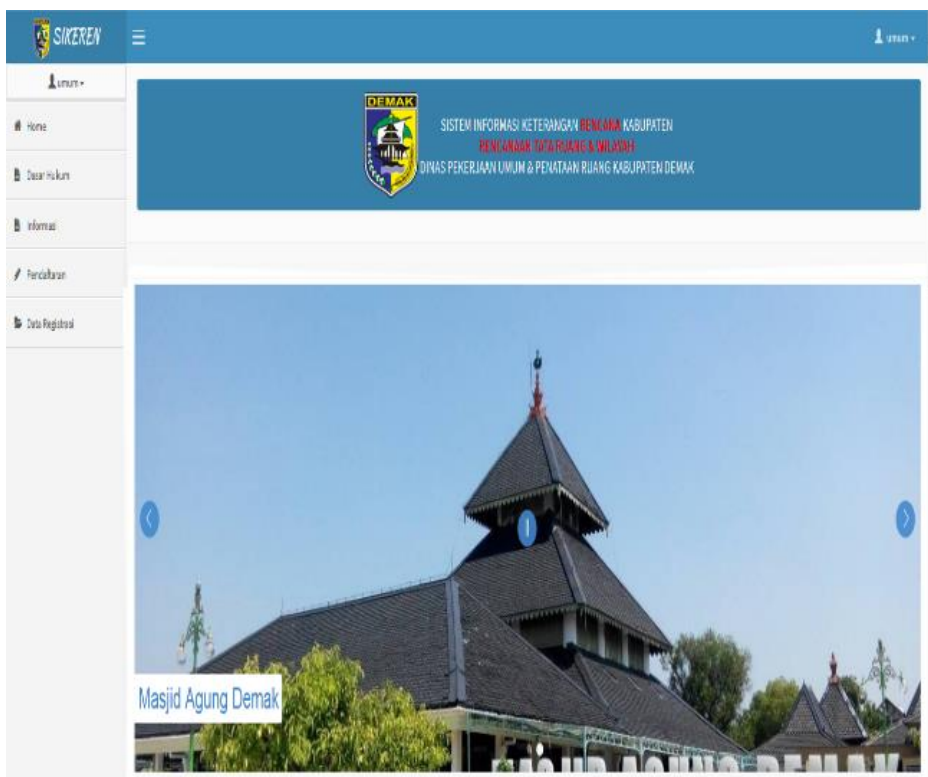

Gambar 7 Halaman Utama Si Keren 
Pengguna dharapkan mengisi user Id dan password lalu clik button "simpan" maka jika proses login benar maka akan menuju ke halaman sesuai level akses masing-masing, dan jika tidak maka akan ada peringatan "username/password salah atau gagal login !" dan kembali pada halaman login.

b. Dasar Hukum

Dasar Hukum yaitu data dasar-dasar hukum dengan model tampilan tabel untuk di download dengan berupa file.

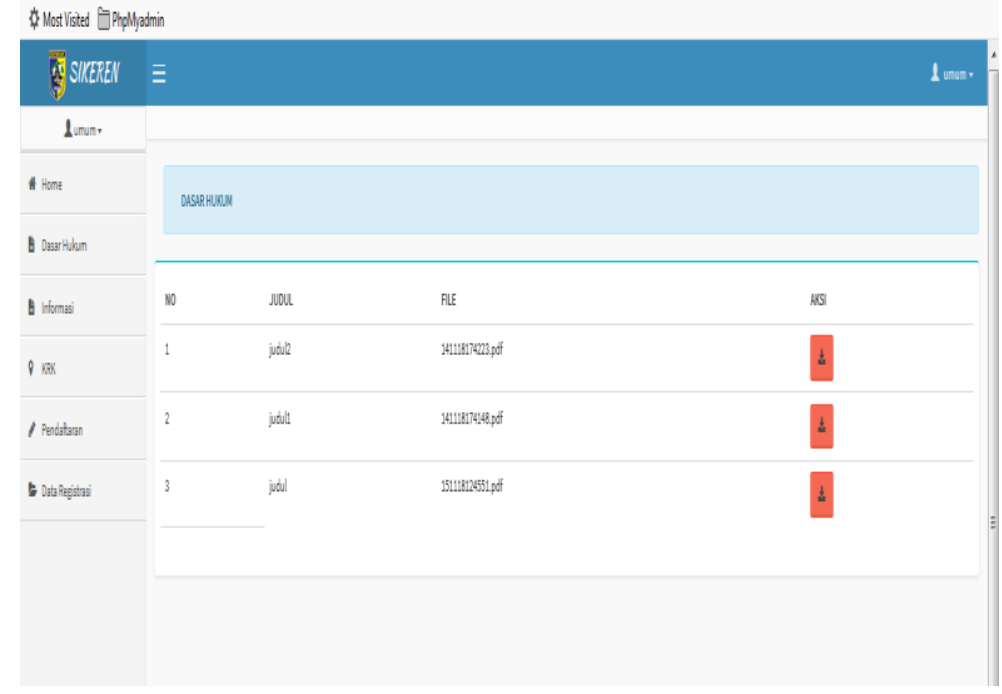

\section{Gambar 8 Dasar Hukum}

Cari file yang diperlukan kemudian untuk download file klik "button" dengan icon panah mengarah kebawah atau download maka data akan otomatis terdownload.

c. Informasi

Informasi yaitu berisi berita/informasi penjelasan tentang fungsi tata ruang, fungsi kawasan beserta penjelasan lainnya yang dapat dpelajari oleh pengguna.

d. KRK (Ketetapan Rencana Kota)

KRK yaitu peta lokasi peruntukan di wilayah kabupaten Demak dengan asumsi beberapa warna yang berbeda untuk mengidentifikasi perwilayah berdasarkan peruntukan wilayah tersebut. 


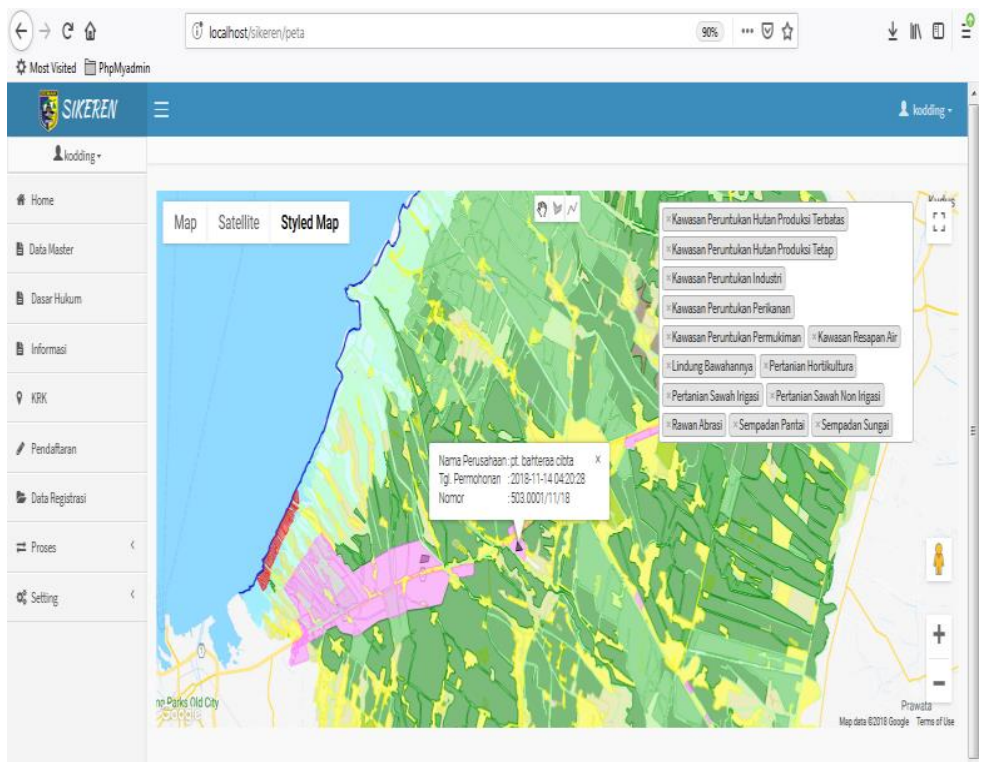

Gambar 9 Ketetapan Rencana Kota beda,

Pada peta di atas terdapat beberapa "button" dengan fungsi yang berbeda-

1. Map yaitu peta dengan tampilan default dari google map.

2. Satellit yaitu peta dengan menampilkan bangunan dari google map.

3. Styled map yaitu dengan menampilkan style dari goole map.

4. Icon telapak tangan yaitu untuk menggeser lokasi di dalam peta.

5. Icon shape yaitu untuk polygon / gambar lokasi di peta.

6. Icon line yaitu untuk garis lokasi di peta.

7. Form select yaitu untuk memilih peruntukan dan menampilkan peruntukan kawasan.

e. Pendaftaran Pemohon

1) Input Pemohon

Pengisian biodata pemohon untuk melengkapi FORM pengajuan permohonan dengan asumsi data akan di verifikasi operator.

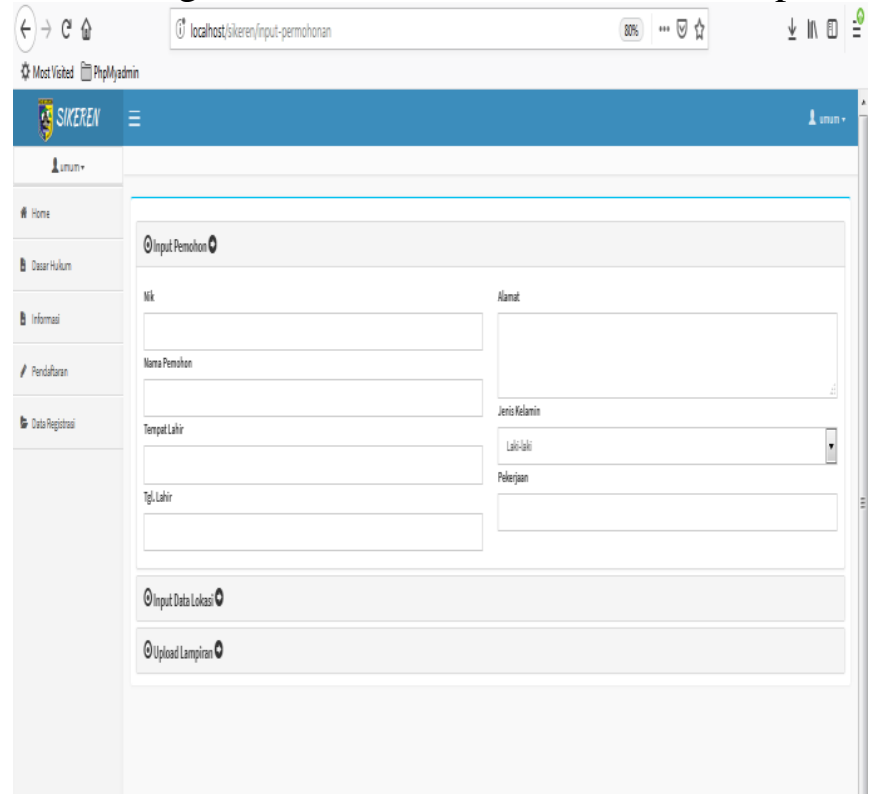

Gambar 10 Input Biodata Pemohon 
Klik "Input Pemohon" dan isi dengan lengkap seluruh data yang diperlukan.

2) Input Data Lokasi

Pengisian data lokasi dan data permohonan dengan benar untuk melengkapi Form pengajuan permohonan dengan asumsi data akan di verifikasi operator.

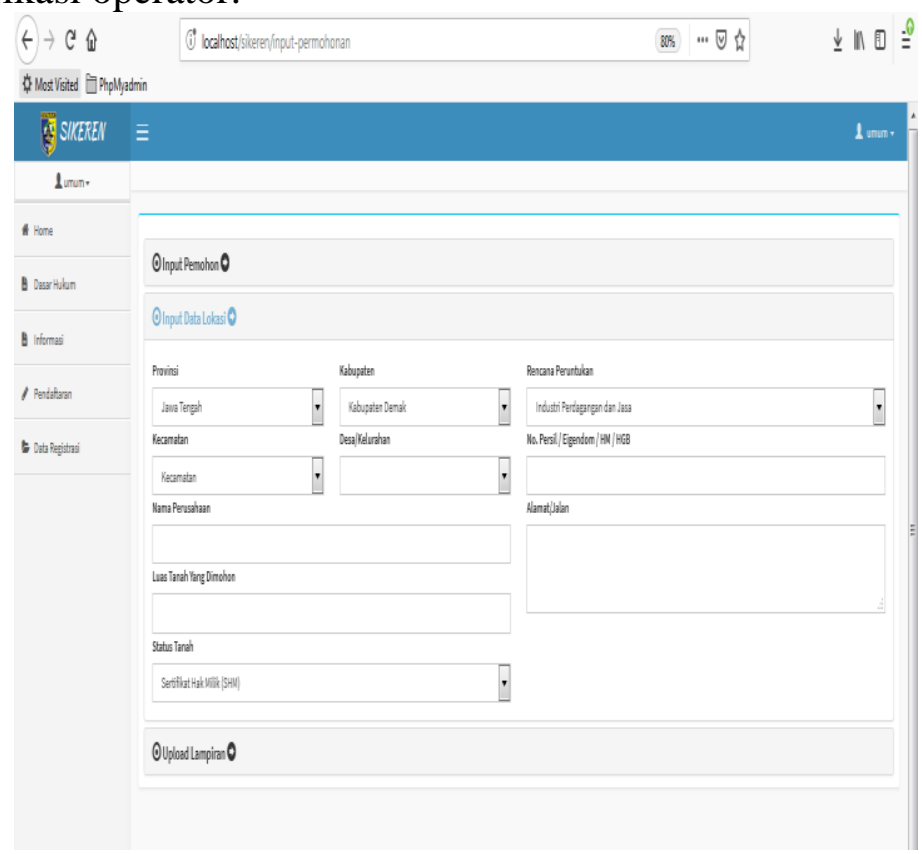

\section{Gambar 11 Input Data Lokasi}

Masih berhubungan dengan biodata pemohon, pemohon diminta mengisi data lokasi peruntukan tanah yang dimohonkan perjinannya sesuai dengan data asli.

3) Upload Lampiran

Permohonan harus melengkapi data dengan melampirkan bukti data diri sertifikat dll untuk selanjutnya di upload dengan asumsi untuk verifikasi pengajuan dan data akan di verifikasi operator.

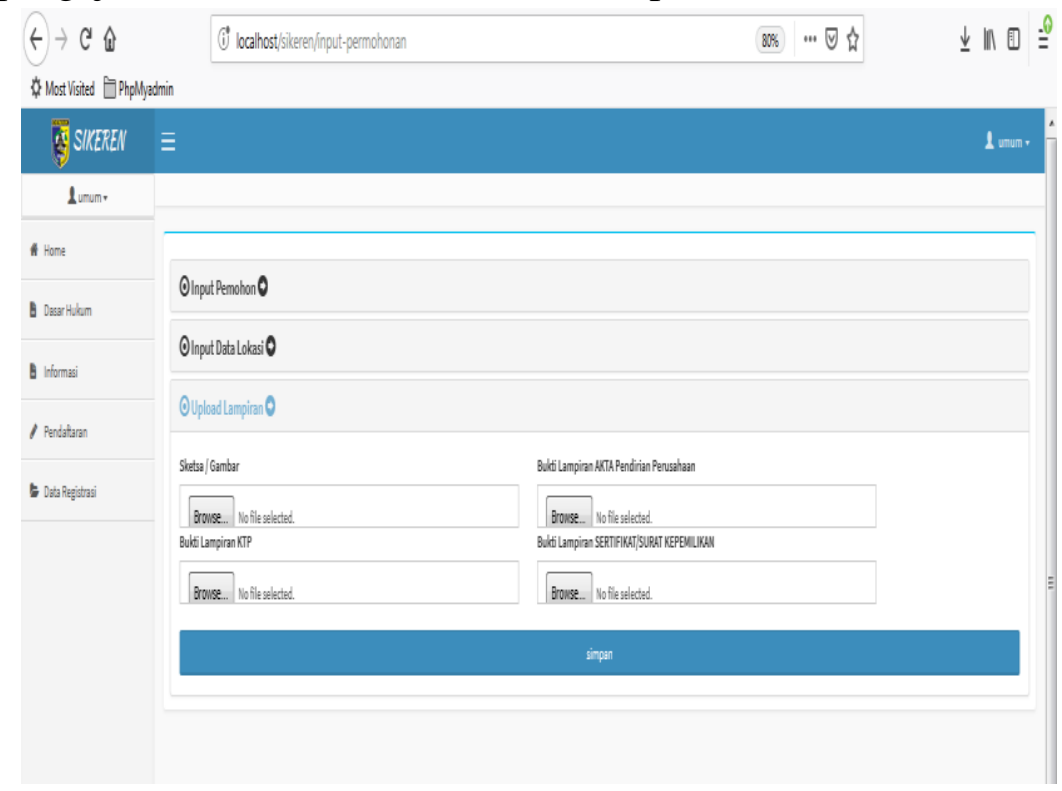

Gambar 12 Penguploadan Lampiran 
4 field untuk upload sesuai label dan data tidak boleh ada yang kosong, jika sudah klik "button" simpan , jika ada text field yang masih kosong maka data tidak akan di proses sistem dan jika sudah lengkap maka data akan disimpan dan sistem akan memberikan informasi "data berhasil disimpan".

f. Data Registrasi

Tampilan daftar data pengajuan permohonan yang sudah tersimpan dalam sistem.

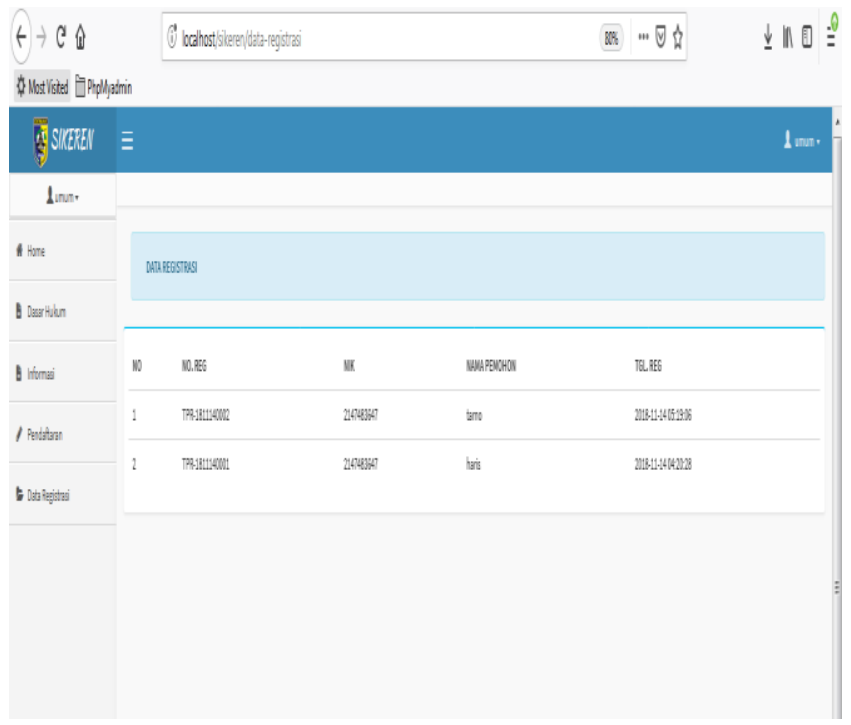

g. Proses Verifikasi

\section{Gambar 13 Data Registrasi}

1) Data Verifikasi:

Tampilan daftar data permohon dengan status pendaftar yang belum di verifikasi oleh operator, halaman ini diakses oleh level operator/administrasi.

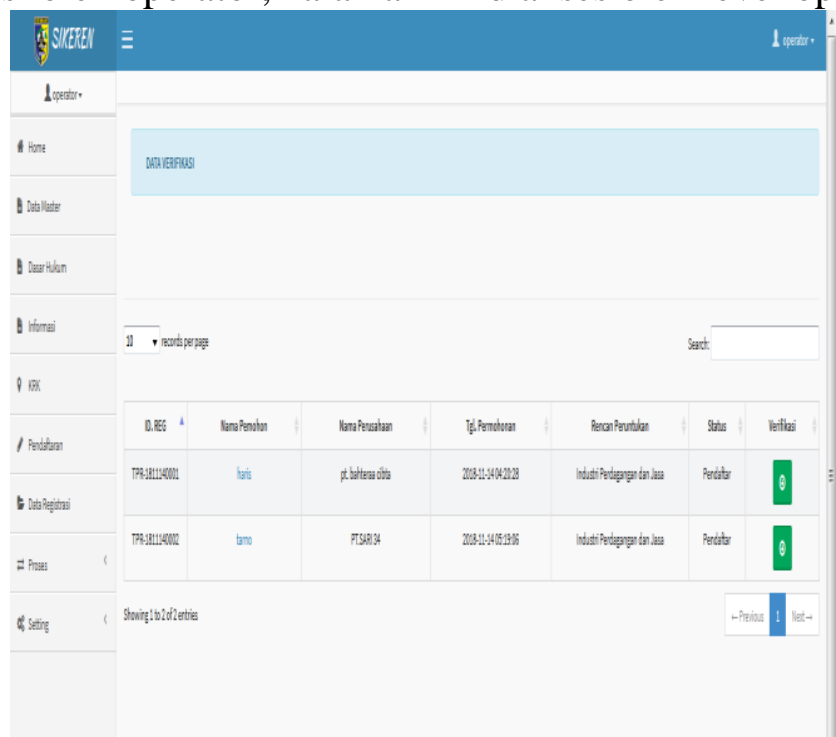

Gambar 14 Data Verifikasi

Ketika button verifikasi diklik form peta berdasarkan nama pemohon dan masuk pada form Verifikasi. 
2) Form Vervikasi

Form Verifikasi yaitu form untuk memverifikasi pemohon sesuai lokasi pemohon dan sistem akan membaca dan memberi status permohonan dengan otomatis sesuai prosedur dari administrator sistem Sikeren.

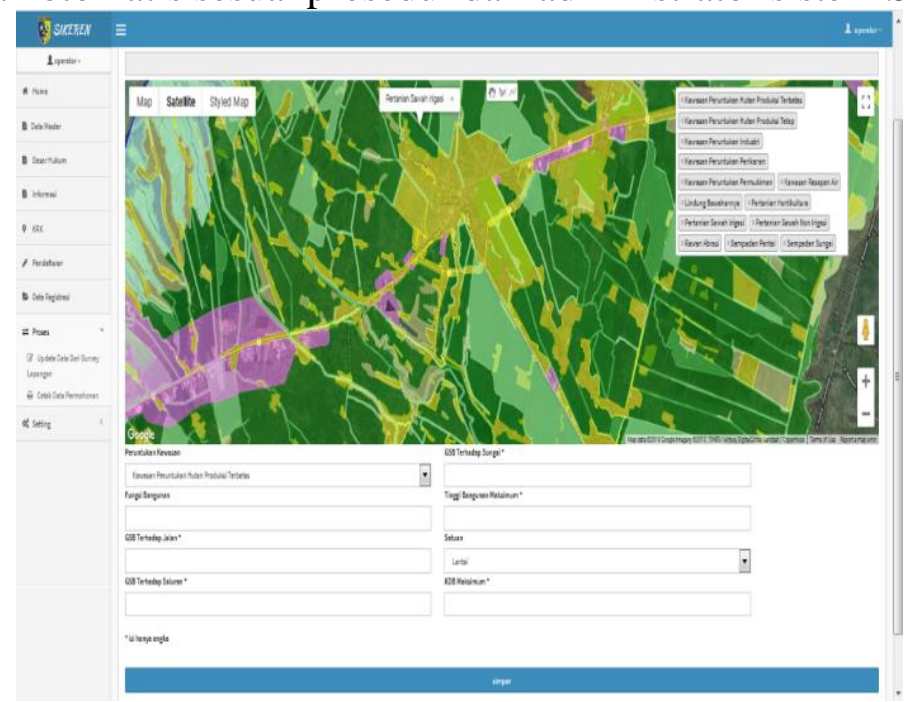

\section{Gambar 15 Form Verifikasi}

Dari peta isi form select peruntukan beberapa atau semua, dan menggambar lokasi sesuai data pemohon, jika sudah selesei lanjut mengisi data yang sesuai dengan data survei dan klik button simpan, maka data akan disimpan dan sekaligus memverifikasi data dari pemohon dan data survei lapangan.

3) Cetak Data Permohonan

Pada form Cetak Data Pemohon akan ditampilkan terlebih dahulu data pemohon yang dapat ditampilkan berdasarkan tanggal mulai, tanggal akhir dan status.

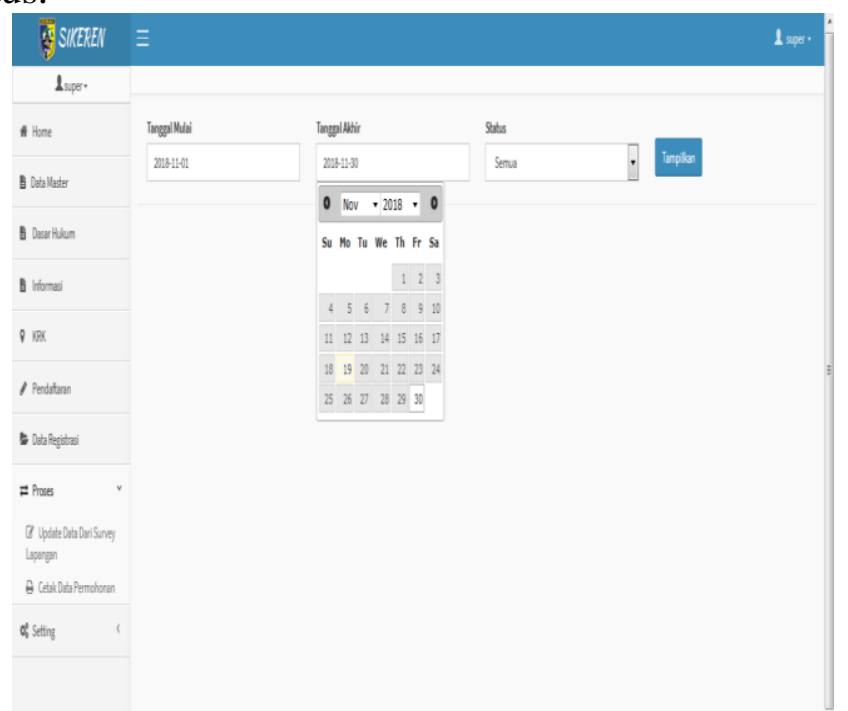

Gambar 16 Form Cetak Data Pemohon

Isi setiap field mulai dari "tanggal mulai" dan "tanggal akhir" terakhir pilih status dan clik button "tampilkan" maka data pemohon akan ditampilkan. 
h. Report

Menu Report yaitu untuk memilih dan menampikan report data antara lain report keterangan dan citra.

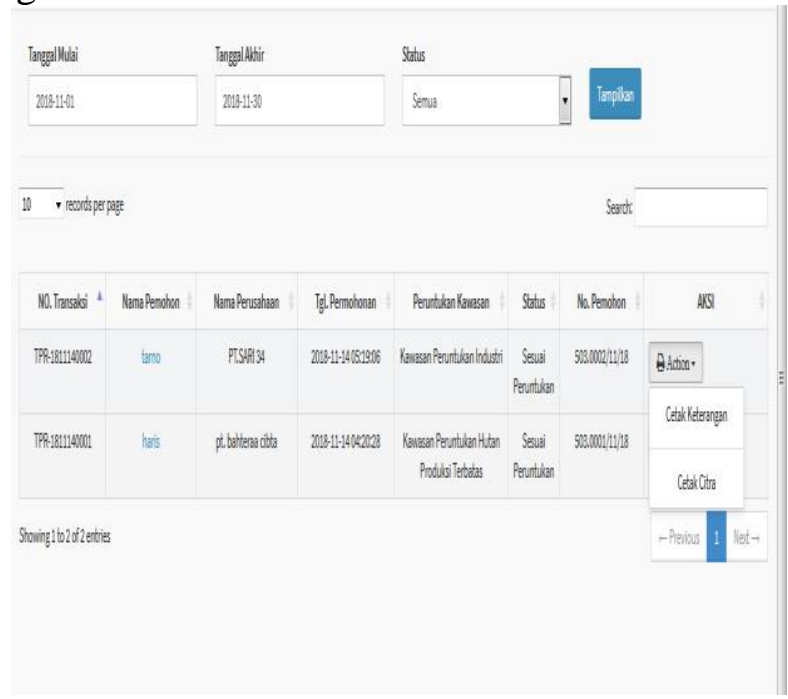

\section{Gambar 17 Menu Report}

Menu report dapat menampilkan data para Pemohon disertai dengan 2 tombol aksi yang dapat dipilih ingin mencetak data tersebut berupa data keterangan atau data citra seperti berikut:

1) Cetak Keterangan

Cetak Data Report yaitu view data keterangan rencana Pemohon untuk siap di cetak.

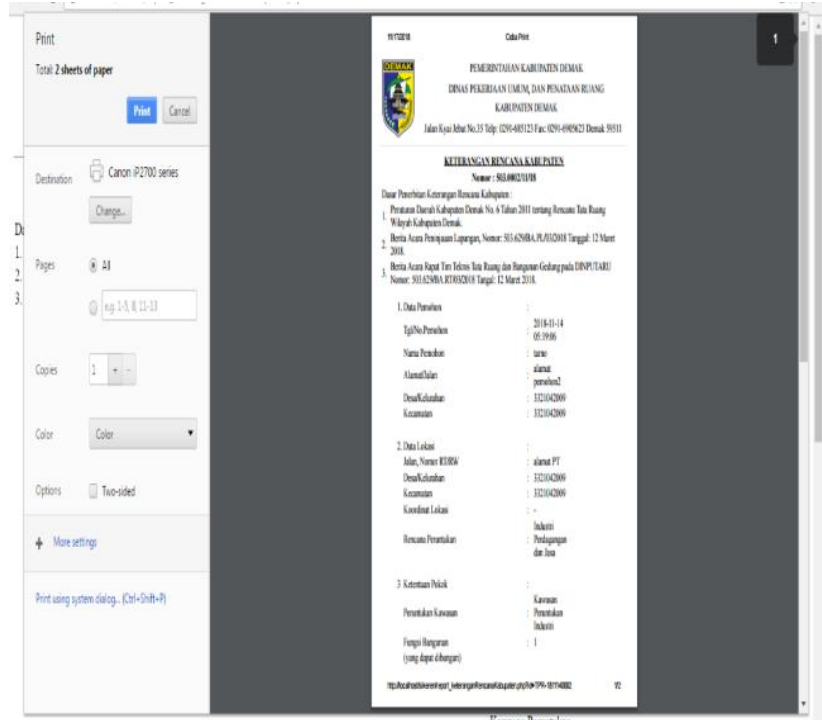

\section{Gambar 18 Cetak Data Keterangan}

Pada panel kiri berisi ada beberapa setting untuk mengatur view report sesuai kebutuhan cetak.

2) Cetak Citra

Cetak Citra yaitu view data citra peta rencana Pemohon yang siap untuk di cetak. 


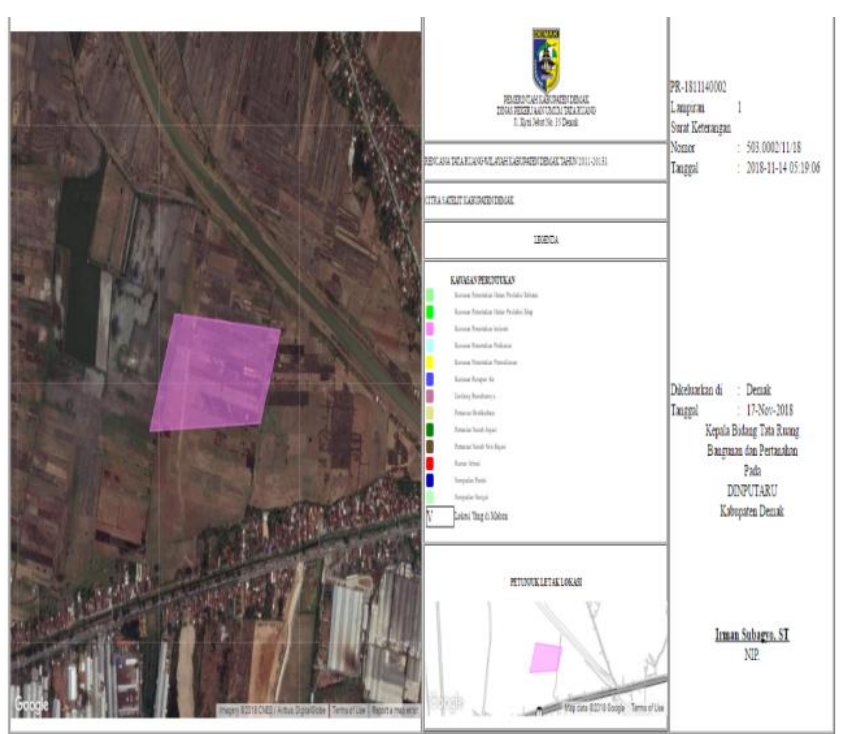

Gambar 19 Cetak Citra

Data berupa peta, jika akan melanjutkan cetak maka klik button cetak pada Google Crome yang berupa modal di sisi kiri atas halaman.

\section{Kesimpulan}

Dari keseluruhan alur pembangunan $\mathrm{Si}$ Keren dapat disimpulkan bahwa pembangunan aplikasi Si Keren kabupaten Demak diharapkan mampu mendukung kinerja dalam menjalankan tupoksi menyusun pelaksanaan perencanaan, pengadaan dan pemeliharaan, dalam melaksanakan pelayanan urusan hukum, hubungan masyarakat dan organisasi pada pemerintahan kabupaten Demak. Sistem ini juga diharapkan menjadi solusi terhadap kebutuhan sistem informasi secara elektronik dan terintegrasinya sistem pelaporan, dengan melakukan overlay terhadap perencanaan, monitoring dan pengendalian RTRW. Aplikasi yang dibangun telah sesuai dengan perencanaan awal yaitu berbasis web dan android, fungsi sebagai sistem informasi keterangan rencana tata ruang dan wilayah guna penentuan kebutuhan perencanaan tersebut. 


\section{BIBLIOGRAFI}

Dewiyanti, Dhini. (2011). Ruang Terbuka Hijau Kota Bandung. Majalah Ilmiah UNIKOM.

Harmono, Harmono. (2018). Tinjauan Politik Hukum Atas Implementasi Kebijakan Pembentukan Badan Usaha Milik Desa. Syntax Literate; Jurnal Ilmiah Indonesia, 2(9), 71-78.

Krisnawati, Eny. (2017). Terciptanya Ruang Terbuka Hijau kota di Surakarta terkait Surakarta sebagai kota layak anak. Jurnal Teknik Sipil Dan Arsitektur, 20(24), 143180.

Nugroho, Vinda Catur. (2015). Evaluasi Ruang Terbuka Hijau di Kecamatan Sleman Kabupaten Sleman. PLANTA TROPIKA: Jurnal Agrosains (Journal of Agro Science), 3(2), 114-121.

Paramesti, N. P. D. (2016). Implementasi Kebijakan Rencana Tata Ruang Wilayah dalam Penyediaan Ruang Terbuka Hijau di Kota Administrasi Jakarta Selatan Provinsi DKI Jakarta. Jurnal Politikologi, 3(1), 1-10. 